\title{
Changes in expression of serine proteases HtrA1 and HtrA2 during estrogen-induced oxidative stress and nephrocarcinogenesis in male Syrian hamster
}

\author{
Dorota Zurawa-Janicka1, Jaroslaw Kobiela ${ }^{2}$, Tomasz Stefaniak², Agnieszka Wozniak ${ }^{3}$, \\ Joanna Narkiewicz ${ }^{1}$, Michał Wozniak ${ }^{4}$, Janusz Limon ${ }^{3}$ and Barbara Lipinska ${ }^{1 凶}$ \\ ${ }^{1}$ Department of Biochemistry, University of Gdansk, Gdańsk, Poland; ${ }^{2}$ Department of General, Endocrine and \\ Transplant Surgery, ${ }^{3}$ Department of Biology and Genetics and ${ }^{4}$ Department of Medical Chemistry, Medical Uni- \\ versity of Gdansk, Gdańsk, Poland
}

Received: 13 November, 2007; revised: 20 January, 2008; accepted: 25 January, 2008

available on-line: 30 January, 2008

\begin{abstract}
Serine proteases HtrA1 and HtrA2 are involved in cellular stress response and development of several diseases, including cancer. Our aim was to examine the involvement of the HtrA proteins in acute oxidative stress response induced in hamster kidney by estrogen treatment, and in nephrocarcinogenesis caused by prolonged estrogenization of male Syrian hamster. We used semiquantitative RT-PCR to estimate the HtrA1 and HtrA2 mRNA levels in kidney tissues, and Western blotting to monitor the amount of the HtrA proteins. Within the first five hours following estrogen administration both $H \operatorname{trA1} \mathrm{mRNA}$ and the protein levels were increased significantly. No changes in the expression of HtrA2 were observed. This indicates that HtrA1 may be involved in the response against oxidative stress induced by estrogen treatment in hamster kidney. During prolonged estrogenization, a significant reduction of the HtrA1 mRNA and protein levels was observed after 6 months of estradiol treatment, while the expression of HtrA2 was significantly elevated starting from the third month. This suggests an involvement of the HtrA proteins in estrogen-induced nephrocarcinogenesis in hamster. Using fluorescence in situ hybridization we localized the HtrA1 gene at the qb3-4 region of Syrian hamster chromosome 2, the region known to undergo a nonrandom deletion upon prolonged estrogenization. It is possible that the reduced level of HtrA1 expression is due to this chromosomal aberration. A full-length cDNA sequence of the hamster HtrA1 gene was obtained. It codes for a $50 \mathrm{kDa}$ protein which has 98 and $96 \%$ identity with mouse and human counterparts, respectively.
\end{abstract}

Keywords: HtrA proteases, oxidative stress, estrogen-induced carcinogenesis, 17- $\beta$-estradiol

\section{INTRODUCTION}

The HtrA family of proteins consists of evolutionarily conserved serine proteases, homologues of the model HtrA protein of the bacterium Escherichia coli. Members of the family are characterized by the presence of a trypsin-like protease domain and at least one PDZ domain at the C-terminal end, and are widely distributed among organisms, prokaryotic as well as eukaryotic, including humans. Prokary- otic HtrAs are involved in the defense against cellular stresses, including the heat and oxidative shocks, and act by degradation of aggregated or misfolded proteins (Clausen et al., 2002).

To date at least four human HtrA homologues have been identified (Clausen et al., 2002) and the best characterized are the HtrA1 and HtrA2 (Omi) proteins.

The HtrA1 gene was initially identified as being repressed in SV40-transformed fibroblasts (Zum-

$\square$ Corresponding author: Barbara Lipinska, University of Gdansk, Department of Biochemistry, Kładki 24, 80-822 Gdańsk, Poland; tel.: (48) 58305 9278; fax: (48) 58301 5741; e-mail: lipinska@biotech.univ.gda.pl

Accession numbers of new nucleotide sequences: EF185310, EF185311

Abbreviations: IAP, inhibitor of apoptosis proteins. 
brunn \& Trueb, 1996). Its $50 \mathrm{kDa}$ protein product contains an N-terminal secretory sequence, a domain with homology to follistatin, and a Kazal-type inhibitor motif in addition to the evolutionarily conserved serine protease and PDZ domains at the Cterminal end (Zumbrunn \& Trueb, 1996; Hu et al., 1998). There are several lines of evidence suggesting that HtrA1 may function as a tumor suppressor gene. Recent studies reported that HtrA1 mRNA was either absent or significantly reduced in ovarian cancers and some brain, liver and breast cancer cell lines (Shridhar et al., 2002; Chien et al., 2004). Primary ovarian cancers showed high frequencies of loss of an allele of microsatellite markers at the HtrA1 locus on 10q26 (Chien et al., 2004). Down-regulation of HtrA1 by antisense transfection promoted anchorage-independent growth, while heterologous overexpression of HtrA1 in an ovarian cell line induced cell death (Chien et al., 2004). Overexpression of HtrA1 in a highly invasive metastatic melanoma cell line inhibited proliferation in vitro and tumor growth in vivo (Baldi et al., 2002). The molecular basis of the HtrA1 function in carcinogenesis is poorly understood.

The HtrA2 (Omi) protein is a tissue-specifically expressed protein whose involvement in apoptosis has been well established. HtrA2 is synthesized as a precursor protein that is autocatalytically processed in mitochondria to produce a mature protein. This processing results in exposure of a tetrapeptide motif, AVPS, allowing interaction with the inhibitor of apoptosis proteins (IAPs). Upon induction of apoptosis the mature HtrA2 protein is released to the cytoplasm, where it interacts with IAPs, neutralizing the IAP-mediated inhibition of caspases, and thus enhancing apoptotic cell death (Hedge et al., 2002; Martins et al., 2002; Verhagen et al., 2002; Yang et al., 2003; Srinivasula et al., 2003). HtrA2 can also induce apoptosis in a caspaseindependent manner via its proteolytic activity, but the mechanism of this process in still not well understood (Cilenti et al., 2003). Recent studies show that HtrA2 can activate apoptosis without being released from mitochondria. This occurs at the early stages of apoptosis by cleaving the mitochondrial anti-apoptotic HAX-1 protein (Cilenti et al., 2004).

There is a strong epidemiological and clinical evidence that estrogens have a role in induction, promotion and progression of a variety of cancers in numerous target organs, including breast, endometrium, ovary, prostate, liver, brain and lymphoid tissues. Chronic administration of estrogens induces a high frequency of mammary cancers in rat strains and malignant kidney tumors in Syrian hamster (Mesocricetus auratus) (Li \& Li, 1990; Liehr, 2000). The Syrian hamster estrogen-induced and -dependent renal cancer is a well-established animal model used to elucidate the cellular and molecular mechanisms involved in estrogen-induced carcinogenesis. Prolonged exposure to natural or synthetic estrogens, administrated to intact or castrated male hamsters, causes microscopic changes (dysplasia, carcinoma in situ) at approx. 4-5 months of treatment, and macroscopically visible kidney tumors after 6 months of estrogenization, with an incidence approaching 100\% (Li \& Li, 1987; Liehr et al., 1988; Li et al., 1995). Although the pathogenesis of the tumor is not clear, oxygen free radicals were proved to play a crucial role in the carcinogenic process (Bhat et al., 2003). 4-Hydroxylation of estradiol seems to be an initial point of oxidoreductive cycling of hydroxylated derivatives of estradiol, its semiquinone and quinone metabolic intermediates, which may cause, apart from non-nuclear lesions, genetic instability, including chromosomal aberrations, gene mutations and amplification (Hodgson et al., 1998; Liehr, 1998; 2001; Cavalieri et al., 2000; Li et al., 2001). In our recent studies we found that the carbonyl group level, a marker of protein oxidation, increased significantly in hamster kidney as soon as after $1 \mathrm{~h}$ exposition to the hormone and progressed further after $3 \mathrm{~h}$ (at that time the increase was at least fourfold) (Kobiela et al., 2007), and was elevated in response to prolonged estradiol treatment (Stefaniak et al., 2002).

Taking into account the facts that: (1) the HtrA1 and HtrA2 proteins belong to the family of proteases the members of which participate in defense against oxidative stress; (2) protein oxidation increases upon estradiol treatment in hamster kidneys; (3) prolonged estradiol treatment causes nephrocarcinogenesis in hamster; (4) HtrA1 is a potential tumor suppressor; (5) HtrA2 is involved in apoptosis, a process which is tightly connected to oncogenesis, we decided to investigate whether HtrA1 and HtrA2 proteins could be involved in estrogen-induced oxidative stress and nephrocarcinogenesis in male Syrian hamster. Our initial goal, presented in this work, was to find out whether oxidative stress and tumorigenesis induced by estrogen treatment cause any changes in the expression of HtrA1 and HtrA2 genes in hamster kidney tissues. We used RTPCR to estimate the HtrA1 and HtrA2 mRNA levels, and Western blotting to monitor the HtrA proteins. Our results, demonstrating significant changes of the expression of the HtrA genes, suggest an involvement of HtrA1 and HtrA2 in oxidative stress and nephrocarcinogenesis, and indicate that the hamster model can be used to clarify the mechanism of the HtrA proteins' action in carcinogenesis.

\section{MATERIALS AND METHODS}

Chemicals. The chemicals were purchased from the following sources: 17- $\beta$-estradiol from 
Sigma (Poznań, Poland); restriction enzymes and molecular mass markers from Fermentas (Vilnius, Lithuania); oligonucleotides used in PCR from Interactiva Biotechnologie GmbH (Ulm, Germany); nitrocellulose type BA $830.2 \mu \mathrm{m}$ for immunoblotting from Schleicher \& Schuell (Dassel, Germany). Other chemicals were purchased from Sigma or Fluka (Poznań, Poland) and were of the highest purity.

Animal treatments. Male Syrian hamsters $(\mathrm{n}=168)$, all 6-8 weeks old, were divided into two groups consisting of 48 and 120 animals. Thirty-six animals of the first group received intraperitoneal injections of $75 \mathrm{mg}$ of $17-\beta$-estradiol suspended in 1 $\mathrm{ml}$ of $0.5 \%(\mathrm{w} / \mathrm{v})$ carboxymethylcellulose saline solution and 12 animals served as an untreated control group. The animals were killed after 1,3 or $5 \mathrm{~h}$ (at each point $n=12$ ) after the injection of estradiol. The second group was divided into two subgroups: subgroup $1(\mathrm{n}=60)$ received subcutaneous implants of $25 \mathrm{mg}$ pellets of $17-\beta$-estradiol every 3 months; subgroup $2(n=60)$ served as a sham-operated control group. The animals from the subgroups were killed after $1,3,6,9$ or 12 months (at each point $\mathrm{n}=12$ ) after initial implantation of estradiol. Kidneys of control and estradiol-treated animals were excised as described previously (Stefaniak et al., 2002). All the procedures concerning animals were approved by the Local Ethical Committee (LEC) and performed according to instructions authorized by the LEC.

Reverse transcriptase (RT). Total RNA was extracted from kidney of male Syrian hamster using RNeasy Isolation kit (Qiagen, Wrocław, Poland). All RNA samples were DNaseI-treated. To obtain cDNA, RNA was reverse-transcribed using MuLV Reverse Transcriptase and oligo $(\mathrm{dT})_{15}$ primer, according to the supplier's protocol (Fermentas).

Amplification of HtrA1 and HtrA2 cDNA fragments. Fragments of cDNA encoding hamster HtrA1 and HtrA2 were amplified in polymerase chain reaction using $p f u$ DNA Polymerase (Fermentas). The following pairs of primers were used: HtrA1 forward1, 5'-ATG GAG CGA CTT ATG AAG CC-3' and HtrA1 reverse1, 5'-CTC CTG CCT CTG CCT AGG G-3'; HtrA1 forward2, 5'-ATT TTC GGC TGT GGT CCA G-3' and HtrA1 reverse2, 5'-CCG ATG GCT ACC ACA AAC TC-3'; HtrA1 forward3, 5'-TGA AAG TGA CAG CAG GCA TC-3' and HtrA1 reverse3, 5'-CTT TGA GGG AAA CAT GAA GTC3'; HtrA2 forward1, 5'-TGG GCT CAT CGT AAC CAA CG-3' and HtrA2 reverse1, 5'-CTA GAA GCA TTT GCG GTG GA-3'. The following hybridization temperatures for each pair of the primers were applied: 57, 60, 57, and $58^{\circ} \mathrm{C}$, respectively. Primers HtrA1 forward1, HtrA1 reverse1, HtrA1 forward2 and HtrA1 reverse 3 were based on the nucleotide sequence of the rat HtrA1 gene (GenBank Accession No. AF179370), and HtrA1 reverse2 and HtrA1 for- ward3 were based on the hamster HtrA1 sequence (obtained during the course of this study, GenBank Accession No. EF185310). Primers HtrA2 forward and $H \operatorname{tr} A 2$ reverse were based on the nucleotide sequence of the rat HtrA2 gene (GenBank Accession No. XM_001066414). The amplified fragments were then sequenced.

Semi-quantitative RT-PCR. Total reversetranscribed cDNA was used in a multiplex reaction with the following primers: HtrA1 forward 5'-AGC CAA AAT CAA GGA TGT GG-3', HtrA1 reverse 5'-ACA TCT GGG AAG TCT CGG TG-3', HtrA2 forward 5'-AAG GAG CCT CTT CCC ACA CTG3', HtrA2 reverse 5'-TAC CGT CTT CTC TCC GAT GG- 3', $\beta$-actin forward 5'-GTC ACC CAC ACT GTG CCC AT-3', $\beta$-actin reverse 5'-GAA ATC GTG CGT GAC ATT AAG -3', $\alpha-M H C$ ( $\alpha$-myosin heavy chain) forward $5^{\prime}$-CGG TGC AGG AGT GTA GGA AT$3^{\prime}, \alpha-M H C$ reverse $5^{\prime}$-CGG AAC TTG GAC AGA TTG GT- $3^{\prime}$. The RT-PCR conditions were optimalized with respect to: (1) primers' concentration, (2) temperature of primer hybridization, (3) $\mathrm{Mg}^{2+}$ concentration, (4) number of cycles, and (5) control for competition between primers. The PCR conditions were always such that the PCR products were in the exponential phase of amplification and amplification did not reach a plateau. The slopes and efficiencies of PCR were similar in multiplex PCRs. This permitted quantitative interpretation of the results. The standard RT-PCR reaction contained a pair of primers: $0.15 \mu \mathrm{M}$ each HtrA1 primer and $0.08 \mu \mathrm{M}$ primers for $\beta$-actin, or $0.15 \mu \mathrm{M}$ each HtrA2 primer and $0.08 \mu \mathrm{M}$ primers for $\alpha$-MHC, $200 \mu \mathrm{M}$ dNTPs, $2 \mathrm{mM} \mathrm{Mg}^{2+}$. To prepare $12 \mu \mathrm{l}$ of PCR mixture $0.6 \mathrm{U}$ of REDTaq Polymerase (Sigma, Poznań, Poland) was used. The conditions for standard amplification were: $95^{\circ} \mathrm{C}$ for $2 \mathrm{~min}$, then 28 cycles of $92^{\circ} \mathrm{C}$ for $1 \mathrm{~min}$ (to amplify $H \operatorname{tr} A 1$ and $\beta$-actin) or 30 cycles of $92^{\circ} \mathrm{C}$ for 1 min (to amplify HtrA2 and $\alpha$-MHC), next $60^{\circ} \mathrm{C}$ for $1 \mathrm{~min}, 72^{\circ} \mathrm{C}$ for $2 \mathrm{~min}$, and final extension at $72^{\circ} \mathrm{C}$ for $5 \mathrm{~min}$. Products of the reaction were resolved in $2 \%(\mathrm{w} / \mathrm{v})$ agarose gel, stained with ethidum bromide and analyzed densitometrically using Quantity One software (BioRad, Warszawa, Poland).

Fluorescence in situ hybridization. Preparation and labeling of hamster HtrA1 probe. Two fragments of hamster HtrA1 gene, of $17000 \mathrm{bp}$ and 5500 bp, were amplified by PCR using genomic DNA extracted from hamster kidney as a template. The following pairs of primers, based on the nucleotide sequence of the hamster HtrA1 gene, were used: FISH forward1, 5'-ATT GTC AGC ACT ACC CAA CGA GG-3' and FISH reverse1, 5'-ACT GAC TGT CCA TTG ATG CTG ATG-3'; FISH forward2, 5'-CTC GTT GGG TAG TGC TGA CAA TC-3' and FISH reverse2, 5'-AAC TTT ATT GCT GAC GTG GTG GA- 3'. AccuTaq LA Polymerase Mix was used 
(Sigma, Poznań, Poland). PCR reactions were carried out according to manufacturer's protocols, applying $0.4 \mu \mathrm{M}$ concentration of each primer. The conditions for amplification were as follows: $98^{\circ} \mathrm{C}$ for $30 \mathrm{~s}$, then 32 cycles of $94^{\circ} \mathrm{C}$ for $10 \mathrm{~s}, 63^{\circ} \mathrm{C}$ for $30 \mathrm{~s}, 68^{\circ} \mathrm{C}$ for $6 \mathrm{~min}$ and $17 \mathrm{~min}$ for amplification of $5500 \mathrm{bp}$ and $17000 \mathrm{bp}$, respectively, and final extension at $72^{\circ} \mathrm{C}$ for $20 \mathrm{~min}$. Amplified genomic DNA fragments were labeled with digoxigenin (DIG) by nick translation (DIG-Nick Translation Mix, Roche, Warszawa, Poland), purified on Nick Translation Columns (Amersham, UK) and next, precipitated. Briefly, to $1 \mu \mathrm{g}$ of DIG-labeled DNA in $0.1 \mathrm{ml}$ of column buffer $(0.1 \%$ $(\mathrm{w} / \mathrm{v})$ SDS, $1 \times \mathrm{SSC}), 0.1 \mu \mathrm{g}$ of herring sperm DNA, 0.1 volume of $3 \mathrm{M}$ sodium acetate $\mathrm{pH} 5.5$ and 2 volumes of cold $96 \%(\mathrm{w} / \mathrm{w})$ ethanol were added. Probe was incubated at $-70^{\circ} \mathrm{C}$ for $30 \mathrm{~min}$ and centrifuged $(15000 \times g, 30 \mathrm{~min})$ at $4^{\circ} \mathrm{C}$. Next, DIG-labeled DNA was washed with $1 \mathrm{ml}$ of cold $70 \%$ (v/v) ethanol, centrifuged again and dissolved in $50 \mu \mathrm{l}$ of TE buffer (10 mM Tris, pH 8.0, 1 mM EDTA, pH 8.0).

Chromosome preparation and in situ hybridization. Metaphase chromosomes were obtained by use of standard procedures after short-term culture of hamster skin fibroblasts in RPMI-1640 medium (Gibco BRL, Paisley, UK) with antibiotics and 10\% (v/v) fetal calf serum (Gibco BRL, Paisley, UK). The hamster HtrA1 genomic probe, $600 \mathrm{ng}$, was used for FISH experiments. Both probe and metaphase chromosomes on the slide were co-denaturated at $75^{\circ} \mathrm{C}$ on a hot plate. Hybridization was performed at $37^{\circ} \mathrm{C}$ in $10 \mu \mathrm{l}$ of hybridization solution $(50 \%(\mathrm{v} / \mathrm{v})$ formamide, $2 \times$ SSC, $10 \%(\mathrm{w} / \mathrm{v})$ dextran sulfate, $0.05 \%$ (v/v) Tween 20). Hybridization took place overnight at $37^{\circ} \mathrm{C}$ and was followed by posthybridization washing in $0.4 \times \mathrm{SSC} / 0.3 \%(\mathrm{v} / \mathrm{v}) \mathrm{NP}-40$ at $73^{\circ} \mathrm{C}$ and then $2 \times \mathrm{SSC} / 0.1 \% \mathrm{NP}-40(\mathrm{v} / \mathrm{v})$ at room temperature. Digoxigenin-labeled DNA was detected using TRITCSheepAntiDigoxigenin primary antibody (Roche, Warszawa, Poland) and TexasRed-DonkeyAntiSheep secondary antibody (JacksonImmunoResearch, Suffolk, UK). Chromosomes were counterstained with DAPI/Antifade (Vector, Burlingame, CA, USA) and hybridization signals were analyzed by using an Axioscope fluorescence microscope (Zeiss, Poznań, Poland) equipped with a cooled CCD camera and run by the CytoVision software for capture and analysis (Applied Imaging, UK).

Construction of plasmids for expression of HtrA proteins. The pET Protein Expression System (Novagen, San Diego, CA, USA) was chosen for expression of the recombinant proteins, fragments of rat HtrA1 and human HtrA2 with $\mathrm{His}_{6}$-tags at their $\mathrm{N}$-terminal end. Fragments of rat HtrA1 and human HtrA2 were amplified by PCR using as a template rat and human cDNA, respectively. A $1047 \mathrm{bp}$ fragment of the rat $H \operatorname{trA} 1 \mathrm{cDNA}$, corresponding to amino ac- ids 133 to 480, was amplified using the following primers, based on the rat HtrA1 gene sequence (GenBank Accession No. AF179370): ratHtrA1 forward 5'-CGG AAT TCA TAT GAA TGG AGC GAC TTA TGA AGC C-3' and ratHtrA1 reverse 5'-GGG ATC CGT CTC CGT CCT CCT AGG AC-3'. The EcoRI/ $\mathrm{NdeI}$ and BamHI restriction endonuclease sites were incorporated into the primer sequences (underlined). The obtained HtrA1 cDNA fragment was firstly subcloned into the EcoRI and BamHI restriction sites of the pUC18 vector and subsequently excised, using $\mathrm{NdeI}$ and BamHI restriction endonucleases, for cloning into the expression plasmid, pET28b (Novagen, San Diego, CA, USA). The obtained construct was named pDZ1. The following primers, based on the human HtrA2 nucleotide sequence (GenBank Accession No. AF141305), were used for amplification of a $975 \mathrm{bp}$ fragment of the human HtrA2 cDNA (amino acids 133 to 458): humHtrA2 forward 5'-CCG GCC GTC CAT ATG GCC GTC CCT AGC C-3' and humHtrA2 reverse 5'-GGT GCT CGA GTC ATT CTG TGA CCT CAG GG-3'. The NdeI and XhoI restriction sites were incorporated into the primer sequences (underlined) so that the resultant HtrA2 cDNA fragment was cloned into the NdeI and XhoI restriction sites of the expression plasmid pET28b. The construct was named pJN1.

Protein expression and purification. Escherichia coli strain BL21(DE3) was transformed with the pDZ1 or pJN1 plasmids and protein expression was induced by a standard procedure (Novagen, San Diego, CA, USA). The recombinant $\mathrm{His}_{6}-\mathrm{rHtrA} 1$ (133-480 aa) and His 6 -humHtrA2 (133-458 aa) proteins were purified by affinity chromatography on Ni-NTA columns according to the manufacturer's instructions (Qiagen, Wrocław, Poland).

Antibody preparation. Polyclonal antibodies against the rat HtrA1 and human HtrA2 recombinant proteins (obtained as described above) were produced in rabbits (Pound, 1998) and then purified by affinity chromatography on Sepharose 4B (Pharmacia $\mathrm{GmbH}$, Freiburg, Germany) conjugated with the rat HtrA1 or human HtrA2 recombinant proteins.

Preparation of kidney tissue homogenates. Each sample, approx. $30 \mathrm{mg}$ of kidney tissue, was homogenized with $0.2 \mathrm{ml}$ of cold $10 \mathrm{mM}$ Tris, $\mathrm{pH}$ 7.4, containing $150 \mathrm{mM} \mathrm{KCl}$, and centrifuged $(15000 \times g$, $30 \mathrm{~min})$ at $4^{\circ} \mathrm{C}$. Supernatant was collected, stored at $70^{\circ} \mathrm{C}$ and subjected to protein analysis.

Protein electrophoresis and assay. Proteins were quantitated by Amido Black staining (Lipinska et al., 1990). SDS/PAGE electrophoresis was carried out according to Laemmli (1970).

Immunoblotting (Western blotting). The immunoblotting was performed essentially as described by Pound (1998). Samples of renal tissues, 
containing equal amounts of total protein, originating from estrogen treated hamsters and an appropriate control group were resolved on the same gel by SDS/PAGE and then subjected to electrotransfer on Immobilon. After that, proteins bound to the membrane surface were stained by a standard procedure with the Ponceau S dye. This step was introduced into the procedure in order to confirm proper protein resolution by SDS/PAGE and electrotransfer, and also to check if protein amounts in the samples were comparable. Polyclonal anti-rat HtrA1 and anti-human HtrA2 immunoglobulins were used as primary antibodies. As the secondary antibody, anti-rabbit polyclonal immunoglobulins conjugated with horseradish peroxidase were used at a dilution of 1/10 000 (Sigma, Poznań, Poland). To visualize the HtrA1 and HtrA2 proteins chemiluminescence detection was performed by using Lumi-Light Western Blotting Substrate from Roche (Warszawa, Poland) and following the manufacturer's protocol. Each assay was repeated 3 times and the differences did not exceed $10 \%$.

Statistical analysis. The RT-PCR products were analyzed densitometrically using Quantity One software, and band intensity ratios were calculated. The RT-PCR signals were averaged from at least three independent experiments using cDNA from kidneys of estrogenized hamsters and control samples. Western blotting data were generated from replicate runs. Student's $t$-tests with Bonferrani's correction were used to compare the groups. Statistica 7.1 PL was used for statistical analysis. Statistical significance was assumed at $P<0.05$.

\section{RESULTS}

\section{Amplification and sequencing of hamster HtrA1 and HtrA2 cDNA fragments}

Since the sequences of hamster HtrA1 and HtrA2 genes were not available, we set out to amplify fragments of HtrA1 and HtrA2 cDNA in order to obtain sequence data necessary for designing primers for the RT-PCR assays of the mRNA levels. Addictionally, the HtrA1 sequence was necessary to design primers used in probe preparation for the hamster HtrA1 gene mapping by fluorescent in situ hybridization (FISH).

To amplify cDNA fragments of hamster HtrA1, PCR was performed using cDNA obtained in reverse transcription of total RNA isolated from hamster kidney. First, specific primers complementary to the rat HtrA1 gene coding sequence were designed to amplify the $759 \mathrm{bp}$ fragment of hamster HtrA1 encoding the proteolytic domain and part of the PDZ domain. Subsequently, two cDNA fragments of hamster HtrA1 were obtained by PCR and primers based on rat HtrA1 and hamster HtrA1 sequences: the first fragment, of $888 \mathrm{bp}$, encoding a signal peptide, the IGF-binding domain and the Kazal-type inhibitor motif from the N-terminus of the HtrA1 protein, and the second fragment, of $447 \mathrm{bp}$, encoding C-terminal PDZ domain of HtrA1 (Fig. 1). The obtained full-length cDNA sequence was deposited in the GenBank (Accession No. EF185310).

A.

B.

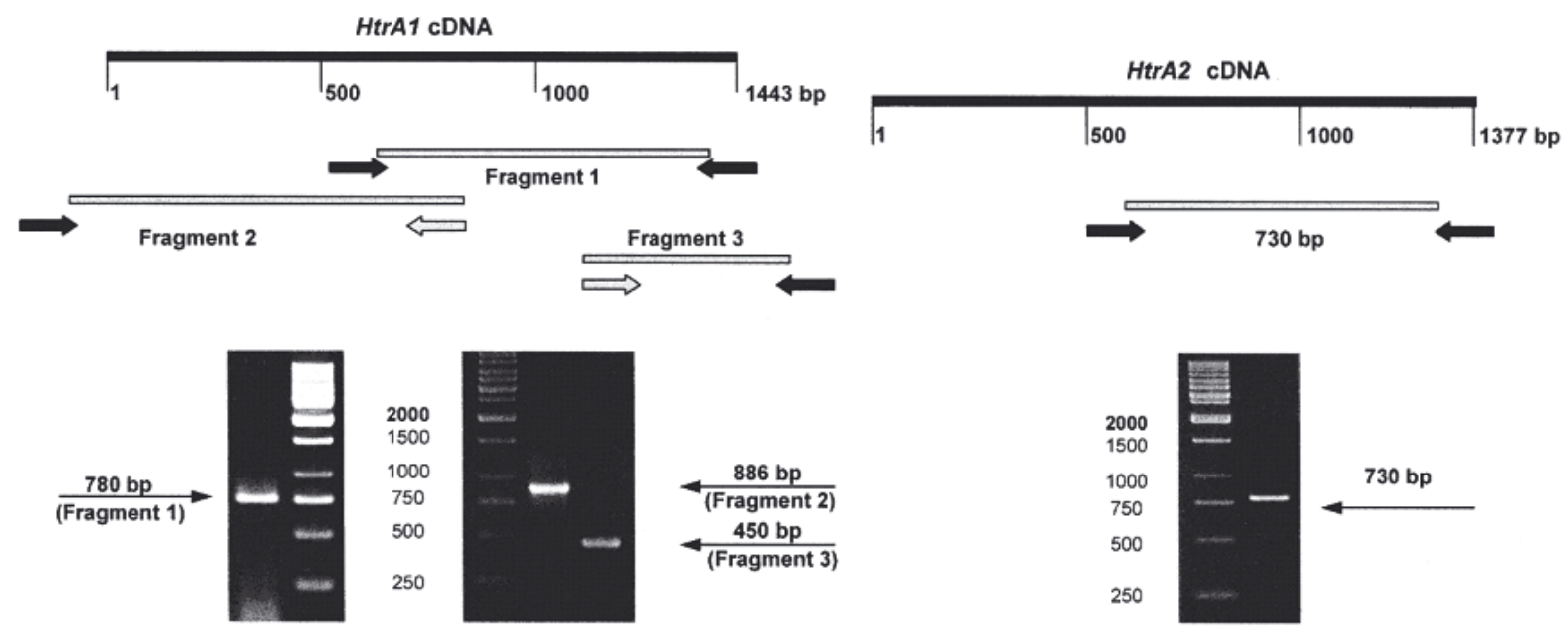

Figure 1. Amplification of hamster HtrA1 and HtrA2 cDNA fragments.

Each panel represents schematic localization of amplified cDNA fragments in coding sequence of HtrA1 (A) and HtrA2 (B), and results of agarose electrophoresis of obtained PCR products. Black arrows represent primers complementary to sequences of rat HtrA1 and HtrA2, designed to amplify cDNA fragments of hamster HtrA1 and HtrA2. Grey arrows represent primers based on hamster HtrA1 cDNA. 
The complete hamster HtrA1 coding sequence of $1443 \mathrm{bp}$, had the highest homology with cDNA of mouse and rat $H \operatorname{trA1}, 91$ and 90\%, respectively, and showed $88 \%$ homology with human HtrA1 cDNA. At the deduced amino acid level the identity of the hamster HtrA1 with the rodent HtrA1 proteins and human HtrA1 was $98 \%$ and $96 \%$, respectively.

RT-PCR was also used to amplify a fragment of the hamster HtrA2 coding sequence using primers based on the rat HtrA2 sequence (Fig. 1). The obtained cDNA fragment of the hamster HtrA2, of $730 \mathrm{bp}$, encoding the proteolytic domain and a fragment of the PDZ domain from the C-terminus, was 93\% identical with mouse HtrA2 cDNA sequence and $90 \%$ identical with human HtrA1 cDNA. At the deduced amino acid level the identity was $97 \%$ and $96 \%$, respectively. The sequence was deposited in the GenBank (Accession No. EF185311).

HtrA1 gene expression, unlike that of HtrA2, is upregulated in response to oxidative stress induced by estradiol in male Syrian hamster kidney

To find out whether oxidative stress induced by estrogen treatment in hamster kidney causes any changes in the expression of HtrA1 and HtrA2 genes, we injected the animals with 17- $\beta$-estradiol and then used a semi-quantitative RT-PCR method to estimate the HtrA1 and HtrA2 mRNA levels, and Western blotting to monitor the amount of HtrA proteins in kidney tissues.

Based on the obtained hamster HtrA1 and HtrA2 coding sequences, two pairs of primers were designed for RT-PCR. The first pair of primers was used for amplification of a 507 bp HtrA1 cDNA fragment, in a multiplex semi-quantitative RT-PCR, with a $654 \mathrm{bp}$ fragment of $\beta$-actin gene as a reference. The method allowed us to determine the relative level of the HtrA1 gene transcript by calculating the ratio of HtrA1 mRNA to $\beta$-actin mRNA. The second pair of primers was used to amplify a $555 \mathrm{bp}$ fragment of HtrA2 cDNA in a multiplex RT-PCR with a $460 \mathrm{bp}$ fragment of the gene encoding $\alpha$-myosin heavy chain $(\alpha-\mathrm{MHC})$ as a reference. This allowed us to calculate the relative level of the HtrA2 mRNA over $\alpha$ MHC mRNA. We estimated the HtrA1 and HtrA2 transcript levels in kidney samples derived from hamsters treated with estrogen for 1,3 or $5 \mathrm{~h}$, and from untreated control animals. The kidney samples were parallely subjected to immunoblotting analysis to estimate the levels of the HtrA proteins. The results are presented in Fig. 2.

Although no changes in the expression of the HtrA2 gene were observed, the HtrA1 mRNA level was increased, starting from the first hour of estrogenization. After 1, 3 and $5 \mathrm{~h}$ from initial
A.

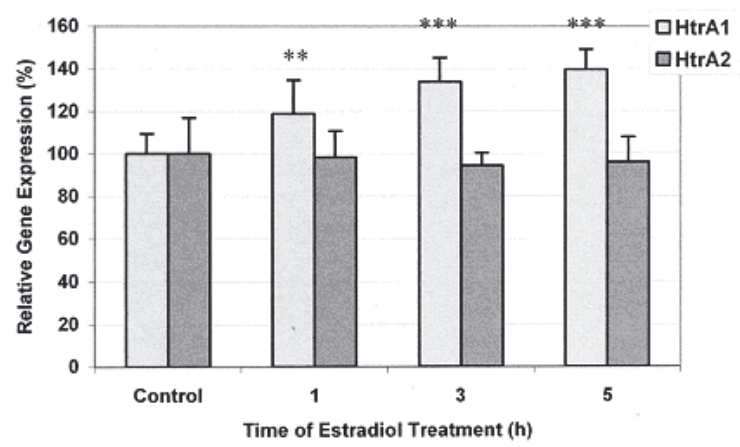

B.

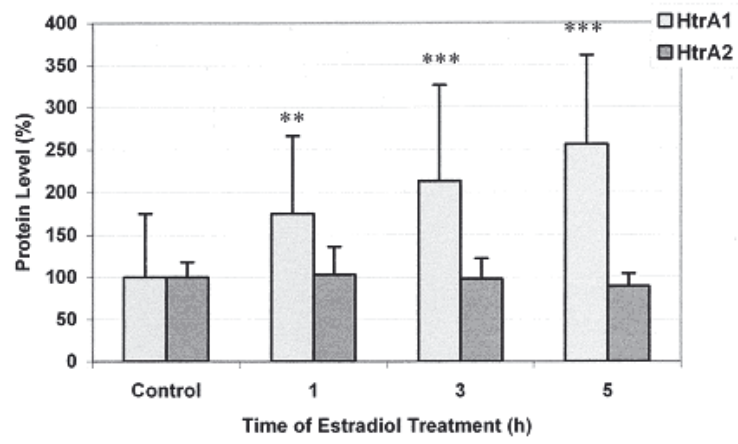

Figure 2. Influence of oxidation stress induced by estradiol treatment on HtrA1 and HtrA2 expression in male Syrian hamster kidney.

(A) Semi-quantitative RT-PCR analysis of HtrA1 and HtrA2 transcript levels in kidneys after 1,3 and $5 \mathrm{~h}$ of estradiol treatment. The relative transcript level of HtrA1 was calculated as ratio of HtrA1 mRNA to $\beta$-actin mRNA. The relative transcript level of HtrA2 was calculated over mRNA of gene coding for $\alpha$-myosin heavy chain $(\alpha-\mathrm{MHC})$. (B) HtrA protein levels in kidneys of estrogenized male Syrian hamsters. Equal amounts of protein from kidney homogenates were resolved by SDS/PAGE and analyzed by immunoblotting using anti-HtrA1 and anti-HtrA2 antibodies and chemiluminescence. Immunoblots were analyzed densitometrically. Each bar represents protein level (HtrA1 or HtrA2) quantitated using Quantity One software and expressed as percentage of control values (from untreated animals). Standard deviation did not exceed $15 \%$. Statistical significance between the control and estradiol-treated groups was determined by Student's $t$-test, data significantly different at $P<0.01$ and $P<0.001$ are marked as a ${ }^{* *}$ and ${ }^{* * *}$ sign, respectively.

estradiol implantation the HtrA1 mRNA level increased significantly by approx. 19, 34 and $40 \%$, respectively (Fig. 2A), compared to the non-treated controls. These observations were supported by Western blotting analysis, which showed increased contents of the HtrA1 protein in the kidney tissues of estradiol-treated animals. After 1, 3 and 5 $\mathrm{h}$ of estrogenization the HtrA1 level was approx. 1.8, 2.1 and 2.6-fold higher comparing to the control group (Fig. 2B). The results were statistically significant. 
A.

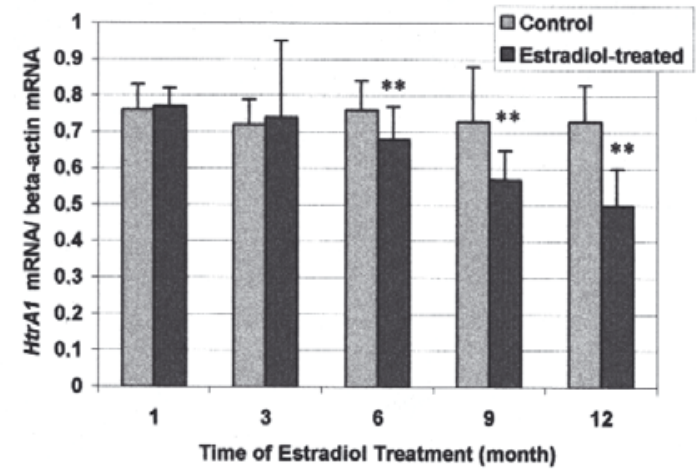

C.

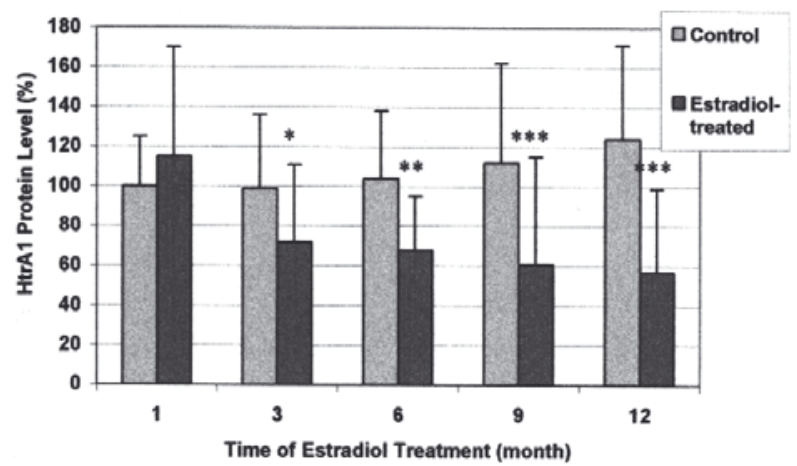

B.

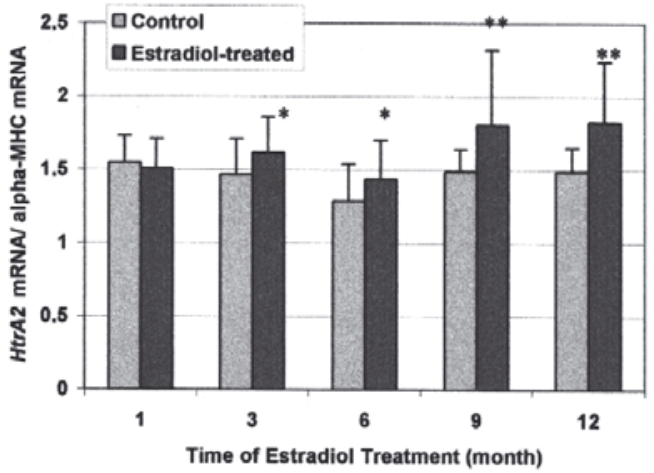

D.

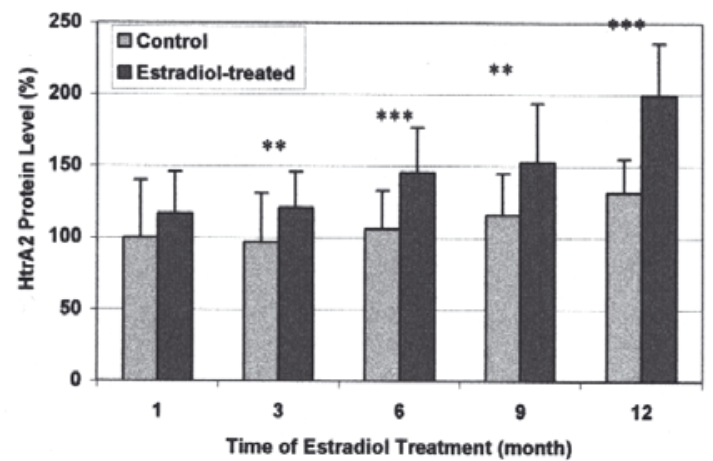

Figure 3. Effects of prolonged estradiol treatment on HtrA1 and HtrA2 gene expression in male Syrian hamster kidneys.

(A, B) Semi-quantitative RT-PCR analysis of HtrA1 and HtrA2 transcript levels in kidneys after 1, 3, 6, 9 and 12 months of estrogenization. The relative transcript level of HtrA1 gene was calculated as the ratio of HtrA1 mRNA to $\beta$-actin mRNA (A). The relative transcript level of HtrA2 gene was calculated over mRNA of the gene encoding $\alpha$-myosin heavy chain $(\alpha-\mathrm{MHC})(\mathrm{B})$. (C, D) HtrA protein levels in kidneys of estrogenized male Syrian hamsters. Equal amounts of protein from kidney homogenates were resolved by SDS/PAGE and analyzed by immunoblotting using anti-HtrA1 (C) and anti-HtrA2 (D) antibodies and chemiluminescence. Immunoblots were analyzed densitometrically. Each bar represents protein level (HtrA1 or HtrA2) quantitated using Quantity One software and expressed as percentage of control values (from untreated animals). Statistical significance between the control and estradiol-treated groups was determined by Student's $t$-test, data significantly different at $P<0.05, P<0.01$ and $P<0.001$ are marked as $a^{*}{ }^{* *}$ and ${ }^{* * *}$ sign, respectively.

Down-regulation of HtrA1 gene expression and increasing expression of the HtrA2 gene accompany nephrocarcinogenesis of male Syrian hamster

To find out if any significant changes in the transcription of the HtrA1 and HtrA2 genes accompany nephrocarcinogenesis of male Syrian hamster caused by prolonged estrogenization, the animals received subcutaneous implants of 17- $\beta$-estradiol and then semi-quantitative RT-PCR was used to estimate relative expression of the genes, and Western blotting to monitor the HtrA protein levels in the kidney tissues. Development of the oncogenic process was monitored by histopathological analysis of kidney tissues performed at consecutive stages of carcinogenesis. Significant, characteristic proliferative changes (interstitial or tubular) were observed starting from the third month of estro- genization and showed an increase in frequency throughout the experiment. Macroscopically visible foci were observed starting from the ninth month (not shown), which is in agreement with other authors' reports and our experience (Oberlay et al., 1991; Hacker et al., 1991; Stefaniak et al., 2002; Kobiela et al., 2003).

The results of the RT-PCR analysis showed that the HtrA1 mRNA level decreased significantly starting from the 6th until 12th month of estradiol treatment (Fig. 3A). These observations were supported by the results of Western blotting analysis which showed a reduced level of the HtrA1 protein in kidney tissues after 6-12 months of estrogenization (Fig. 3C).

In contrast, expression of the HtrA2 gene in the kidney was increased by the estradiol treatment. We observed a significantly increased transcript lev- 


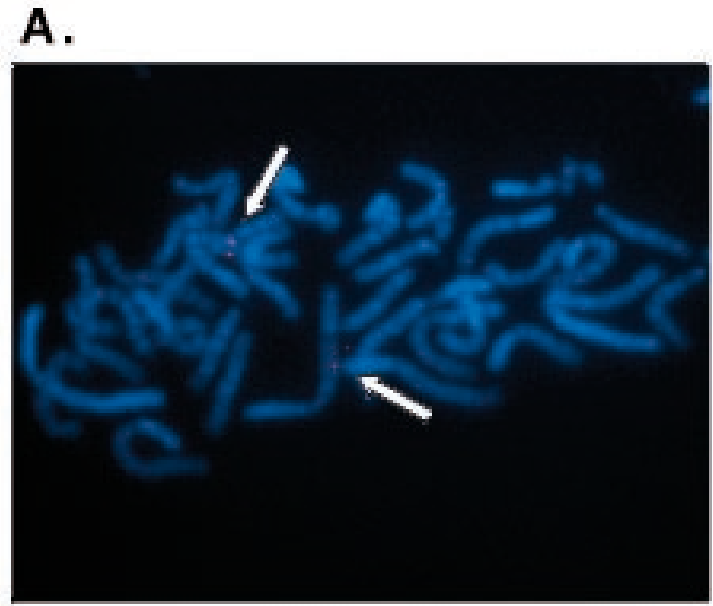

B.

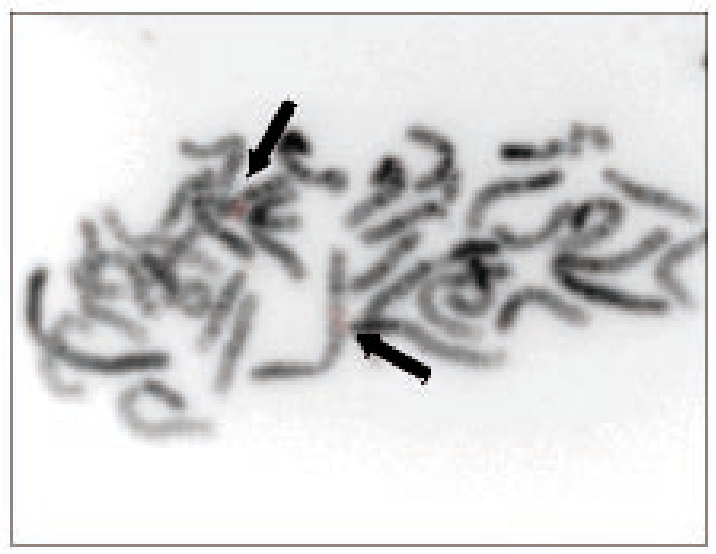

C.

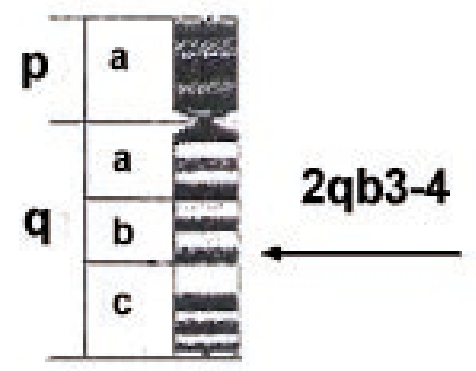

Figure 4. Localization of HtrA1 gene to chromosome 2 by fluorescence in situ hybridization (FISH).

Hybridization signals on homologous chromosomes corresponding to the HtrA1 locus are indicated by arrows. (A) Image of metaphase chromosomes (DAPI stained) after FISH with hamster HtrA1 genomic probe. (B) Reversed image of the same DAPI-stained metaphase chromosomes. (C) Ideogram of Syrian hamster chromosome 2 (Mamaeva, 2002).

el of the HtrA2 gene (Fig. 3B) and a higher HtrA2 protein content after 3-12 months from the initial estradiol implantation (Fig. 3D).
Localization of HtrA1 gene on Syrian hamster chromosome by fluorescent in situ hybridization (FISH)

To localize the HtrA1 gene on hamster chromosomes, we performed a FISH study using as a probe a mixture of two fragments of HtrA1 genomic sequence. The fragments, of $17 \mathrm{~kb}$ and $5.5 \mathrm{~kb}$, were amplified using PCR and labeled with digoxigenin. The probe was hybridized to metaphase spreads obtained from cultured normal hamster fibroblasts. Staining of the same chromosome spreads with DAPI gave a G-banded pattern, which permitted the HtrA1 gene to be localized to chromosome region 2qb3-4 (Fig. 4), based on a published map of Syrian hamster chromosomes (Mamaeva, 2002).

\section{DISCUSSION}

The HtrA1 and HtrA2 proteins belong to the HtrA family of serine proteases that participate in defense against cellular stresses causing aberrations in protein structure, for example heat and oxidative stress. Human HtrA proteins are involved in cell growth and differentiation, apoptosis, and disturbances in their function may induce several diseases, including cancer (Clausen et al., 2002). There is accumulating evidence suggesting that HtrA1 may function as a tumor suppressor, though the molecular basis for the suppression is poorly understood. The role of HtrA2 protein in apoptosis is well established but so far there are no data available indicating its involvement in carcinogenesis. In this study we set out to investigate the involvement of the HtrA1 and HtrA2 proteases in estrogen-induced oxidative stress and carcinogenesis. Our aim was to find out whether oxidative stress and tumorigenesis, both induced by estrogen treatment, cause any changes in the expression of the HtrA1 and HtrA2 genes. To achieve this goal we used an animal model in which carciongenesis in the kidney of male Syrian hamster was induced by $17-\beta$-estradiol (natural female sex hormone). This experimental model is a reliable rodent model of human estrogen-dependent breast carcinoma (Roy \& Liehr, 1999; Liehr, 2000).

We demonstrated both at the mRNA and protein levels that expression of the HtrA1 gene was significantly increased in hamster kidney in response to acute estrogen treatment while there were no statistically significant changes in the HtrA2 gene expression (Fig. 2). Our previous studies assessing the dynamics of oxidative damage in kidney of estradiol-treated male Syrian hamster showed that among the cellular macromolecules, proteins appear to be the primary target of oxidative damage. Protein oxidation increased as soon as $1 \mathrm{~h}$ after exposition to the hormone while DNA oxidative damage 
was unchanged at that time and increased only after $5 \mathrm{~h}$ of estradiol treatment (Kobiela et al., 2007). Taking these facts into account it is possible that upregulation of the $H \operatorname{tr} A 1$ gene, observed as early as after one hour of estrogenization, may be a result of induction of pathways involved in the response to the appearance of oxidatively damaged proteins, and the HtrA1 protease could be an important element of the oxidative stress response. Although our present study concerned the influence of acute estradiol treatment on HtrA1 expression in hamster kidney tissue, the response mechanism in which HtrA1 participates may be more general. Up-regulation of HtrA1 expression and autocatalytic activation of the protease were demonstrated in ovarian cell lines under treatment with agents causing protein and DNA damage, such as cisplatin. It has been suggested that HtrA1 may function as a stress-induced protease whose main function is removal of unfolded proteins (Chien et al., 2006). Our results are in agreement with this hypothesis; moreover, they suggest that HtrA1 could participate in the response to estradiol-induced oxidative stress that triggers early stages of estrogen-dependent carcinogenesis in hamster kidney.

We showed both at the mRNA and protein levels that prolonged estrogenization influenced significantly expression of both the HtrA1 and HtrA2 genes. After 6-12 months of estrogen treatment, leading to nephrocarcinogenesis, we observed a significant down-regulation of the HtrA1 gene (Fig. 3A and $\mathrm{C}$ ). Numerous studies have been published supporting the hypothesis that HtrA1 may function as a tumor suppressor involved in promoting cell death and that down-regulation of HtrA1 is correlated with malignant progression and metastasis, and also with poor response to chemotherapy. Down-regulation of the HtrA1 gene expression was observed in several types of cancers, including ovarian ones, some breast cancer cell lines, and also metastatic melanomas (Shridhar et al., 2002; Baldi et al., 2002; Chien et al., 2004; 2006). It has been shown that in primary ovarian cancers a decrease of HtrA1 expression is correlated with the loss of heterozygosity of the HtrA1 gene and its epigenetic inactivation by hypermethylation (Chien et al., 2004). In the present study, using fluorescence in situ hybridization, we localized the Syrian hamster HtrA1 gene to chromosome 2, region qb3-4 (Fig. 4). This region has been shown by Papa et al. (2003) as a region that undergoes a nonrandom deletion upon prolonged estradiol treatment. It is possible that the observed reduced level of HtrA1 gene expression could be due, at least partially, to the chromosomal aberration. If that is the case, then our results would suggest that the loss of the chromosomal region encoding HtrA1 is a general mechanism occurring during oncogenesis.
Our results showed that during the acute oxidative stress HtrA1 level went up (after 1-5 h) but after a prolonged and milder stress (6 months) it decreased, in spite of the fact that after 6 months of estrogenization the level of protein oxidation was elevated (Stefaniak et al., 2002) as well as the level of 8-iso-prostaglandin $\mathrm{F}_{2 \alpha^{\prime}}$ a known marker of oxidant stress (Bhat et al., 2003). We assume that HtrA1 is induced by the oxidant stress - and this happens in hours - but after several months of the continuous exposure to reactive oxygen species HtrA1 regulation changes. One of the reasons of this change may be a deletion of the fragment of chromosome where the HtrA1 gene is located.

We found that prolonged estrogenization caused an increase of $\mathrm{HtrA2}$ expression starting from the 3rd month of the estradiol treatment (Fig. $3 \mathrm{~B}$ and $\mathrm{D})$. Among the human homologues, HtrA2 was found to be up-regulated in response to heat shock or tunicamycin treatment, both of which cause aberrations in protein structure (Gray et al., 2000). As a mitochondrial protein, HtrA2 provides protein quality control in the mitochondrium (Jones et al., 2003), an important target of estrogen action and a predominant source of reactive oxygen species, also of those arising under estrogen action (Felty \& Roy, 2005). It is possible that the observed increase of HtrA2 level is caused, at least partially, by accumulation of aberrant proteins in the mitochondrium. It is known that mature HtrA2 is released from the mitochondrium to the cytoplasm, degrades inhibitors of apoptosis proteins and activates a cascade of caspases (Yang et al., 2003; Srinivasula et al., 2003; Seong et al., 2004). It has been shown by Jin et al. (2002), that HtrA2 is implicated in a p53-dependent apoptosis. Under treatment with etoposide - a DNA damaging agent that induces apoptosis in a p53-dependent manner - the HtrA2 gene expression is upregulated in HeLa cells and primary mouse thymocytes. Taking into account the fact that genetic instability is a common feature of estrogen-induced carcinogenesis in Syrian hamster kidney (Banerjee et al., 1992; 1994; Hodgson et al., 1998; Li et al., 1999), it is possible that the observed increase of HtrA2 expression could be an element of the cellular response to DNA damage. This is, to our knowledge, the first time that changes in HtrA2 gene expression during carcinogenesis were described.

Summarizing, the observed changes in the HtrA1 and HtrA2 genes' expression suggest that both HtrA proteins could be involved in estrogen-induced nephrocarcinogenesis of male Syrian hamster, though acting by different mechanisms. Additionally, the HtrA1 protease could participate at a very early stage of estrogen treatment, most probably as a response to estrogen-induced oxidative stress. 
While achieving the main goals of this work, we have sequenced the Syrian hamster HtrA1 cDNA and found that it codes for a protein of a predicted molecular mass of $50 \mathrm{kDa}$, with a high identity (96\%) to human HtrA1.

Our findings open the way for further investigation of the molecular basis of the HtrA protein action in carcinogenesis, using the Syrian hamster as a model. One of the possible pathways of investigation is to study the interplay between the HtrA proteases and TGF $\beta$ proteins, since recent studies by Oka et al. (2003) have shown that HtrA1 participates in the regulation of signaling by various proteins of the TGF $\beta$ family, including TGF $\beta 1$ and TGF 32 , which are regulators of cell growth and differentiation. HtrA1 inhibits signaling by TGF $\beta$ presumably by preventing receptor activation (Oka et al., 2003).

\section{Acknowledgements}

This work was supported by grants from the State Committee for Scientific Research (KBN, No. 1074/P04/2004/26) and from University of Gdańsk (BW No. 1460-5-0348-6).

\section{REFERENCES}

Baldi A, De Luca A, Morini M, Battista T, Felsani A, Baldi F, Catricala C, Amantea A, Noonan DM, Albini A, Natali PG, Lombardi D, Paggi MG (2002) The HtrA1 serine protease is down-regulated during human melanoma progression and repress growth of metastatic melanoma cells. Oncogene 21: 6684-6688.

Banerjee SK, Banerjee S, Li SA, Li JJ (1992) Cytogenetic changes in renal neoplasms and during estrogen-induced carcinogensis. In Hormonal Carcinogenesis. Li JJ, Nandi S, Li SA, eds, pp 247-250. Springer-Verlag, New York.

Banerjee SK, Banerjee S, Li SA, Li JJ (1994) Induction of chromosomal aberrations in Syrian hamster renal cortical cells by various estrogens. Mutat Res 311: 191-197.

Bhat HK, Calaf G, Hei TK, Loya T, Vadgama JV (2003) Critical role of oxidative stress in estrogen-induced carcinogenesis. Proc Natl Acad Sci 100: 3913-3918.

Cavalieri E, Frenkel K, Liehr JG, Rogan E, Roy D (2000) Estrogens as endogenous genotoxic agents - DNA adducts and mutations. J Natl Cancer Inst Monogr 27: 75-93.

Chien J, Staub J, Hu SI, Erickson-Johnson MR, Couch FJ, Smith DI, Crowl RM, Kaufmann SH, Shridhar V (2004) A candidate tumor suppressor HtrA1 is down-regulated in ovarian cancer. Oncogene 23: 1636-1644.

Chien J, Aletti G, Baldi A, Catalano V, Muretto P, Keeney GL, Kalli KR, Staub J, Ehrmann M, Cliby WA, Lee YK, Bible KC, Hartmann LC, Kaufmann SH, Shridhar V (2006) Serine protease HtrA1 modulates chemotherapyinduced cytotoxicity. J Clin Invest 116: 1994-2004.

Cilenti L, Lee Y, Hess S, Srinivasula S, Park KM, Junqueira D, Davis H, Bonventre JV, Alnemri ES, Zervos AS (2003) Characterization of a novel and specific inhibitor for the pro-apoptotic protease Omi/HtrA2. J Biol Chem 278: 11489-11494.
Cilenti L, Soundarapandrian MM, Kyriasis GA, Stratico V, Singh S, Gupta S, Bonventre JV, Alnemri ES, Zervos AS (2004) Regulation of HAX-1 anti-apoptotic protein by Omi/HtrA2 protease during cell death. I Biol Chem 279: 50295-50301.

Clausen T, Southan C, Ehrmann M (2002) The HtrA family of proteases: implications for protein composition and cell fate. Mol Cell 10: 443-455.

Felty Q, Roy D (2005) Estrogen, mitochondria, and growth of cancer and non-cancer cells. http://www.carcinogenesis.com/content/4/1/1

Gray CW, Ward RV, Karran E, Turconi S, Rowles A, Viglienghi D, Southan C, Barton A, Fantom KG, West A, Savopoulos J, Hassan NJ, Clinkenbeard H, Hanning C, Amegadzie B, Davis JB, Dingwall C, Livi GP, Creasy CL (2000) Characterization of human HtrA2, novel serine protease involved in the mammalian cellular stress response. Eur J Biochem 267: 5699-5710.

Hacker HJ, Vollmer G, Chiquet-Ehrismann R, Bannasch P, Liehr JG (1991) Changes in the cellular phenotype and extracellular matrix during progression of estrogen-induced mesenchymal kidney tumors in Syrian hamster. Cell Pathol 60: 213-223.

Hegde R, Srinivasula SM, Zhang ZJ, Wassell R, Mukattash R, Cilenti L, DoBois G, Lazebnik Y, Zevros AS, Fernandes-Alnemri T, Alnemri ES (2002) Identification of Omi/HtrA2 as mitochondrial apoptotic serine protease that disrupts inhibitors of apoptosis protein-caspase interaction. J Biol Chem 277: 432-438.

Hodgson AV, Ayala-Torres S, Thompson EB, Liehr JG (1998) Estrogen-induced microsatellite DNA alterations are associated with Syrian hamster kidney tumorigenesis. Carcinogenesis 19: 2169-2172.

Hu S-I, Carozza M, Klein M, Nantermet P, Luk D, Crowl RM (1998) Human HtrA, an evolutionarily conserved serine protease identified as a differentially expressed gene product on osteoarthritic cartilage. J Biol Chem 273: 34406-34412.

Jin S, Kalkum M, Overholtzer M, Stoffel A, Chait BT, Levine AJ (2002) CIAP1 and the serine protease HtrA2 are involved in a novel p53-dependent apoptosis pathway in mammals. Genes Dev 17: 359-367.

Jones JM, Datta P, Srinivasula SM, Li W, Gupta S, Zhang Z, Davies E, Hajnoczky G, Saunders TL, Van Kauren ML, Fermandes-Alnemri T, Meisler MH, Alnemri ES (2003) Loss of mitochondrial protease activity causes the neuromuscular disorder of $m n d 2$ mutant mice. $\mathrm{Na}$ ture 425: 721-727.

Kobiela J, Kubasik-Juraniec J, Stefaniak T, Krajewski J, Belleza G, Bucciarelli E, Kryger P, Lachinski A, Gruca Z, Spodnik JH, Wozniak M (2003) The correlation of protein peroxidation with morphological changes in experimental oestradiol-induced carcinogensis. Folia Morphol 62: 341-346.

Kobiela J, Stefaniak S, Krajewski J, Kalinska-Blach B, Zurawa-Janicka D, Lachinski A, Gackowski D, Olinski R, Nowak J, Knap N, Lipinska B, Sledzinski Z, Wozniak M (2007) Dynamics of estrogen oxidative damage. Acta Biochim Polon 54: 289-295.

Laemmli UK (1970) Cleavage of structural proteins during assembly of the head of bacteriophage T4. Nature 227: 680-685.

Li JJ, Li SA (1987) Estrogen carcinogenesis in Syrian hamster tissues: role of metabolism. Fed Proc 46: 1858-1863.

Li JJ, Li SA (1990) Estrogen carcinogenesis in hamster tissue: a critical review. Endocrine Rev 11: 524-531.

Li JJ, Li SA, Oberley TD, Parsons JA (1995) Carcinogenic activities of various steroidal and nonsteroidal estro- 
gens in the hamster kidney: relation to hormonal activity and cell proliferation. Cancer Res 55: 4347-4351.

Li JJ, Hou X, Banerjee SK, Liao D-ZJ, Maggout F, Norris SJ, Li SL (1999) Overexpression and amplification of c-myc in the Syrian hamster kidney during estrogen carcinogenesis: a probable critical role on neoplastic transformation. Cancer Res 59: 2340-2346.

Li JJ, Veroha SJ, Davis MF, Tawfik O, Hou X, Li SA (2001) ER and PR in renomedullary interstitial cells during Syrian hamster estrogen-induced tumorigenesis: evidence for receptor-mediated oncogenesis. Endocrinology 142: 4006-4014.

Liehr JG, Sirbasku DA, Jurka E, Randetath K, Randerath E (1988) Inhibition of estrogen-induced renal carcinogenesis in male Syrian hamster by tamoxifen without decrease in DNA adduct levels. Cancer Res 48: 779-783.

Liehr GJ (1998) Catecholestrogens in the induction of tumors in the kidney of the Syrian hamster. Adv Pharmacol 42: 824-828.

Liehr GJ (2000) Is estradiol a genotoxic mutagenic carcinogen? Endocrine Rev 21: 40-54.

Liehr GJ (2001) Genotoxicity of the steroidal oestrogens oestrone and oestradiol: possible mechanism of uterine and mammary cancer development. Hum Reprod Update 7: 273-281.

Lipinska B, Zylicz M, Georgopoulos C (1990) The HtrA (DegP) protein, essential for Escherichia coli survival at elevated temperatures, is an endoprotease. J Bacteriol 172: 1791-1797.

Mamaeva SE (2002) Atlas of Chromosomes of Human and Animal Cell Lines. Scientific World, Moscow.

Martins LM, Iaccarino I, Tenev T, Gschmeissner S, Totty NF, Lemoine NR, Savopoulos J, Gray CW, Creasy CL, Dingwall C, Downward J (2002) The serine protease Omi/HtrA2 regulates apoptosis by binding XIAP through a Reaper-like motif. J Biol Chem 277: 439-444.

Oberlay TD, Gonzalez A, Lancher LJ, Oberlay LW, Li JJ (1991) Characterization of early lesions in estrogen-induced Syrian hamster. Cancer Res 51: 1922-1929.

Oka C, Tsujimoto R, Kajikawa M, Koshiba-Takeuchi K, Ina J, Yano M, Tsuchiya A, Ueta Y, Soam A, Kanda H, Matsumoto M, Kawaichi M (2004) HtrA1 serine protease inhibits signaling mediated by $\operatorname{Tgf} \beta$ family proteins. Development 131: 1041-1053.
Papa D, Li SA, Li J (2003) Comparative genomic hybridization of estrogen-induced ectopic uterine-like stem cell neoplasms in the hamster kidney: nonrandom chromosomal alterations. Mol Carcinog 38: 97-105.

Pound JD (1998) Immunochemical protocols. In Methods in Molecular Biology, vol 80. JM Walker JM, ed. Humana Press, New Jersey, Totowa.

Roy D, Liehr JG (1999) Estrogen, DNA damage and mutations. Mutat Res 424: 107-115.

Seong YM, Choi JY, Park HJ, Kim KJ, Ahn SG, Song GH, Kim IK, Kang S, Rhim H (2004) Autocatalytic processing of HtrA2/Omi is essential for induction of caspasedependent cell death through antagonizing XIAP. J Biol Chem 279: 37588-37596.

Shridhar V, Sen A, Chien J, Staub J, Avula R, Kovats S, Lee J, Lillie J, Smith DI (2002) Identification of underexpressed genes in early- and late-stage primary ovarian tumors by suppression subtraction hybridization. Cancer Res 62: 262-270.

Srinivasula SM, Gupta S, Datta P, Zhang ZJ, Hedge R, Cheong N, Fernandes-Alnemri T, Alnemri ES (2003) Inhibitor of apoptosis proteins are substrates for the mitochondrial serine protease Omi/HtrA2. J Biol Chem 278: 31469-31472.

Stefaniak T, Krajewski J, Kobiela J, Makarewicz W, Stanek A, Asano M, Kondo R, Wakabayashi T, Gruca Z, Wozniak M (2002) Protein oxidation in male Syrian hamster kidney during estrogen-induced carcinogenesis. Pathophysiology 8: 269-273.

Verhagen AM, Silke J, Ekert PG, Pakush M, Kaufmann H, Connolly LM, Day CL, Tikoo A, Burke R, Wrobel C, Moritz RL, Simpson RJ, Vaux DL (2002) HtrA2 promotes cell death through its serine protease activity and its ability to antagonize inhibitor of apoptosis proteins. J Biol Chem 277: 445-454.

Yang QH, Church-Hajduk R, Ren J, Newton NL, Du C (2003) Omi/HtrA2 catalytic cleavage of inhibitor of apoptosis (IAP) irreversibly inactivates IAP and facilities caspase activity in apoptosis. Genes Dev 17: 1487-1496.

Zumbrunn J, Trueb B (1996) Primary structure of a putative serine protease specific for IGF-binding proteins. FEBS Lett 398: 187-192. 